\title{
死別への適応と故人との継続する絆との関連
}

\author{
一故人との継続する絆の適応性における自伝的記憶のはたらき(1)一 \\ ○山中亮 ${ }^{1}$. 田上恭子 ${ }^{2}$ \\ ( 1 名古屋市立大学大学院人間文化研究科 $\cdot 2$ 愛知県立大学看護学部) \\ キーワード：継続する絆, 死別体験, 適応
}

Adjustment to Bereavement and Continuing Bonds

Akira YAMANAKA ${ }^{1}$ and Kyoko TAGAMI ${ }^{2}$

( ${ }^{1}$ Graduate School of Humanities and Social Sciences, Nagoya City Univ., ${ }^{2}$ School of Nursing \& Health, Aichi Prefectural Univ.)

Key Words: continuing bonds, bereavement, adjustment

\begin{abstract}
目 的
死別への適応に関する理論一つとして，故人との絆を死別 後も保ち続けることが死別への適応において重要であるとい う継続する絆(Continuing Bonds)理論が注目されている(Klass et al., 1996)。特に死別への適応・不適応と絆のありようとの関 連について関心が高まっている。本研究では, 死別への適応 を現在の死別反応から捉えることとし，どのような死別体験 がどのように適応に影響を及ぼすのか，また死別への適応と 継続する絆との関連を明らかにすることを目的とする。
\end{abstract}

方 法

\section{1. スクリーニング調査}

株式会社クロス・マーケティングのリサーチ専門データベ 一スにモニターとして登録している一般成人の中から，1,107 名(年齢範囲 18-88 歳)を対象にスクリーニング調査を実施し た。調查内容は, 性別, 年齢, 日本語版 WHO-5 精神的健康状 態表(岩佐他, 2007), 大切な方との死別経験の有無, 本調查一 の協力意思の有無, であった。実施は同社に委託した。結果, 精神的健康状態が良好であるとされるカットオフポイント 13 点以上の者で, 死別経験があり，本調査への協力意思がある 者は 667 名であった。

\section{2. 本調査}

1) 調査対象者と手続き: スクリーニングされた 667 名から 400 名を本調査の対象とした。実施は同社に委託した。

2) 調查内容: (1) 死別体験の内容(a.故人との続柄, b. 死別年, c. 生前の故人の大切さと親密性(各 $0 \sim 100), \mathrm{d}$. 死別の予期, e. 死 別時の苦痛, f. 苦痛からの回復の程度。 $\mathrm{d} \sim \mathrm{f}$ は 6 件法), (2)故 人との継続する絆(日本語版 Continuing Bonds Scale(以下 CBS; 中里他, 2008)を用いた。11 項目 5 件法), (3)死別反応(中里(2006) による死別反応尺度を用い, 最近 2 週間の状態を尋ねた。「悲 哀感と思慕」「イメージと思考の再体験」の 2 因子構造。13 項 目 4 件法)。この他，故人に関する記憶の項目が含まれた。

\section{3. 倫理的配慮}

本研究は, 名古屋市立大学人間文化研究科研究倫理審査委 員会の審査・承認を受け実施された。

\section{結 果}

有効回答 390 名(男性 194 名，女性 196 名; 平均年齢 54.65 歳, 年齢範囲 18-85 歳)を分析対象とした。

\section{1. 死別体験が死別反応に及ぼす影響}

「悲哀感と思慕」「イメージと思考の再体験」には性差，年齢 との関連は認められなかった。故人との続柄について, 回答 の多かった上位 $3 つ($ 親, 祖父母, 配偶者・パートナー; $N=340$ ) の間で下位尺度得点をそれぞれ比較したところ有意な主効果 が認められ $\left(F(2,337)=4.96, M S e=36.88, p<.01, \eta^{2}=.03 ; F(2,337)=\right.$ $\left.5.07, M S e=26.74, p<.01, \eta^{2}=.03\right)$, 配偶者・パートナーとの死別 者は親及び祖父母との死別者より死別反応が高かった $(p<.05)$ 。

その他の死別体験内容に関する変数との相関を求めたとこ ろ,「悲哀感と思慕」と経過年以外の変数との間で有意な相関
が認められた $(r=.13-44, p \mathrm{~s}<.05)$ 「「イメージと思考の再体験」 は, すべての変数との相関が有意であった $(r=.11-38, p \mathrm{~s}<.05)$ 。

2. 死別反応と故人との継続する絆との関連

変数間の相関を求めたところ, 「悲哀感と思慕」「イメージと 思考の再体験」と CBS 得点との間にはともに有意な正の相関 が認められた $(r=.53, r=.39, p \mathrm{~s}<.001)$ 。

\section{3. 死別体験と故人との継続する紏との関連}

変数間の相関を求めたところ,「生前の故人の大切さ」,「生 前の故人との親密さ」,「死別時の苦痛」と CBS 得点とに有意 な正の相関が認められた $(r=.27, r=.31, r=.38, p \mathrm{~s}<.001)$ 。また 「回復の程度」と CBS 得点との間に有意な負の相関が認めら れた $(r=-.26, p<.001)$ 。

4. 死別体験が死別反応に及ぼす影響における故人との継続 する絆の間接効果の検討

独立变数を死別体験の各变数, 従属变数を死別反応の 2 下 位尺度, 媒介変数を $\mathrm{CBS}$ 得点として, 統計分析ソフト $\mathrm{HAD}$ (清 水，2016)を用いて媒介分析を行った。死別体験については, 関連の見られた「続柄」「生前の故人の大切さ」「生前の故人 との親密さ」「死別時の苦痛」「回復の程度」を検討した。 Bootstrap 法 (サンプリング回数 2,000) を用いて間接効果を検 討したところ, 死別反応 2 下位尺度いずれにおいても,「続柄」 以外全てで $\mathrm{CBS}$ の間接効果が有意だった $(p s<.001)$ 。なお「回 復の程度」からの直接効果については, 有意性を保っていた。

$$
\text { 考 察 }
$$

本研究の結果から, 死別体験の特徵が現在の死別反応に及 ぼす影響については, 故人との継続する絆の強さが媒介して いることが明らかとなった。すなわち, 精神的健康状態が良 好な者では, 絆を強く感じていると死別反応を強めると考え られ, 必ずしも故人との継続する絆が死別への適応を高める わけではないことが示唆される。

\section{引用文献}

岩佐 一他 (2007). 日本語版「WHO-5 精神的健康状態表」の信 頼性ならびに妥当性一地域高齢者を対象とした検討一 厚 生の指標, 54, 48-55.

Klass, D., et al. (1996). Continuing bonds: New understandings of grief. New York: Taylor \& Francis.

中里 和弘 (2006). 青年期における祖父母との死別に関する 研究(第 1 報)一祖父母の死に対寸る認識と死別反応につい ての検討一 生老病死の行動科学, 11, 11-20.

中里 和弘他 (2008). 日本語版 Continuing Bonds Scale (「故人 との絆の継続」評価尺度)の作成 日本心理学会第 72 回大会 発表論文集, 376 .

清水裕士 (2016). フリーの統計分析ソフト HAD: 機能の紹介 と統計学習・教育, 研究実践における利用方法の提案 メ ディア・情報・コミュニケーション研究, $1,59-73$.

謝 辞

本研究は科研費(課題番号 26380935)の助成を受けた。 